\title{
IMPLEMENTASI PROGRAM LEAGUE OF CHANGE DALAM PERUBAHAN PERILAKU ODHA MENGHADAPI STIGMA HIV/ AIDS
}

\author{
Charisma Asri Fitrananda \\ Redaksi Harian Umum Pikiran Rakyat
}

\begin{abstract}
ABSTRAK
Tujuan dari penelitian ini adalah untuk mengetahui latar belakang dilaksanakannya Program League Of Change, pola komunikasi pada program League Of Change dan dampak yang dirasakan oleh ODHA setelah mengikuti program League Of Change. Pendekatan penelitian yang digunakan adalah kualitatif, dengan paradigma konstruktivisme dan jenis penelitian studi kasus. Subjek penelitian adalah orang-orang yang mempunyai peran dalam program League Of Change yang dipilih secara purposif. Pengumpulan data diperoleh melalui wawancara mendalam, observasi dan studi pustaka. Data yang diperoleh akan melewati tahapan triangulasi sebagai sarana pengecekan, pemeriksaan dan perbandingan kembali dengan derajat kepercayaan suatu informasi yang dilakukan oleh seseorang yang ahli dalam bidang HIV/AIDS. Hasil penelitian ini menunjukkan bahwa latar belakang dilaksanakannya program League Of Change berasal dari tiga faktor kepentingan yaitu ODHA, organisasi, dan masyarakat. Pola komunikasi pada program League Of Change terjadi melalui dua proses komunikasi yaitu dari komunitas kepada ODHA, dan dari komunitas kepada masyarakat. Dampak yang dirasakan oleh ODHA setelah mengikuti program League Of Change dibagi menjadi dua bagian yaitu dampak internal, dan dampak eksternal.
\end{abstract}

Kata-kata Kunci: ODHA, HIV/AIDS, perilaku

\section{IMPLEMENTATION LEAGUE OF CHANGE'S PROGRAM TO CHANGE ODHA'S BEHAVIOR TO CONFRONT HIVIAIDS STIGMA}

\begin{abstract}
The purpose of this research are to find background, communication pattern, and impact of League Of Change's programt perceived by ODHA (acronym of Orang Dengan HIV/AIDS or people with HIV/AIDS) after attending League Of Change's program. This research uses qualitative approach with constructivism paradigm and case study method. The subjects are those people who have a role in League Of Change's program, which was purposively selected. Data collection process are through in depth interviews, observations and literature studies. Data obtained also coming through stages of triangulation as a means of checking, re-examination and comparison with the degree of confiedence in any information thet would be done by an expert in the field of HIVIAIDS. The results of this research reveals that background of League Of Change's program derived from three factors of interest, such as ODHA, organizations and society. Communication patterns in League Of Change's program occurs through two processes, from comunnity to ODHA and from community to society. impact felt by ODHA after attending League Of Change's program divided into two parts, internal impact and external impact.
\end{abstract}

Keywords: People living with HIV, HIV/AIDS, behavioral

Korespondensi: Charisma Asri Fitrananda, S.I.Kom., M.I.Kom. Redaksi Harian Umum Pikiran Rakyat. Jl. Soekarno Hatta no 147 Bandung 40223, Kotak Pos 1254. Email: fitrananda@ymail.com 


\section{PENDAHULUAN}

League of Change merupakan salah satu program "Kampanye Indonesia Tanpa Stigma" yang dijalankan oleh Rumah Cemara, program ini berisi turnamen sepak bola jalanan (street soccer) dan sesi sharing feeling secara informal. Turnamen street soccer ini merupakan sebuah kompetisi sepak bola pertama yang digelar di Indonesia dengan peserta Orang Dengan HIV/ AIDS (ODHA). Dalam turnamen ini, sebanyak 120 peserta ikut ambil bagian. Mereka tidak hanya berasal dari Jawa Barat saja, tetapi dari provinsi lain, yaitu DKI Jakarta, Banten, Sumatera Utara, Kalimantan Selatan, Jawa Timur, Sulawesi Selatan, dan DI Yogyakarta.

Rumah Cemara, sebuah Lembaga Swadaya Masyarakat (LSM) di Kota Bandung merupakan salah satu lembaga yang bergerak di bidang penanggulangan HIV/AIDS dan Narkotika. Beberapa tahun terakhir ini, Rumah Cemara sedang giat melakukan penghapusan stigma HIV/AIDS melalui program-program yang positif seperti olah raga, salah satunya League of Change. Penghuni Rumah Cemara adalah sebagian besar mantan pecandu narkoba dan ODHA yang menerima sanksi sosial dari masyarakat sekitar dan bahkan dari keluarga dekat. Karena sebagian masyarakat masih memandang mereka sebelah mata, maka melalui program League of Change inilah Rumah Cemara memberikan pembuktian kepada masyarakat umumnya dan kepada diri sendiri khususnya bahwa ODHA bisa melakukan kegiatan yang positif dan bisa berprestasi di bidang olah raga.

Program League of Change yang dilaksanakan oleh Rumah Cemara tidak hanya ingin memberikan pesan bahwa League of Change bukanlah hanya sekadar ajang sepakbola, tapi yang lebih penting lagi adalah bagaimana para pemain bisa melakukan perubahan dalam hidup mereka, dan masyarakat memberi dukungan pula pada mereka. Walaupun program ini pada awalnya tidak mendapatkan dukungan Pemerintah Indonesia, tetapi tidak membuat semangat Rumah Cemara untuk menghapus stigma HIV/AIDS dengan program yang positif menjadi padam.

Dalam kasus ini, program League of Change digunakan sebagai alat yang menghorisontalkan kelanjutan Kampanye Indonesia Tanpa Stigma setiap tahunnya oleh Rumah Cemara. Tidak hanya itu, keunikan dari kasus program program League of Change berbeda dengan program Rumah Cemara yang lainnya. Pasalnya dari beberapa program yang dilaksanakan oleh Rumah Cemara, program ini yang dianggap paling efektif untuk memberikan informasi mengenai HIV/AIDS dan mendapatkan penghargaan dari beberapa lembaga nasional dan internasional, salah satunya dari Kementrian Pemuda dan Olahraga Republik Indonesia.

Implementasi Program League of Change bermuara pada aktivitas, adanya aksi, tindakan, atau mekanisme suatu sistem yang merupakan suatu kegiatan terencana dan dilakukan secara sungguh-sungguh berdasarkan acuan norma tertentu untuk mencapai tujuan kegiatan. Tujuan dalam Program League of Change adalah untuk membuat sebuah kampanye sosial melalui kegiatan sepak bola untuk memberikan kesempatan yang sama kepada kelompok marjinal agar dapat mengaktualisasikan dirinya melalui sepakbola.

Rumah Cemara tidak dapat hanya memberikan penyuluhan karena pengetahuan dari masyarakat juga sangat terbatas. Jadi perlu pendekatan yang sangat taktis dan strategis, oleh karena itu Rumah Cemara menggunakan sepak bola karena olah raga ini populer di masyarakat dan bisa diterima oleh semua kalangan masyarakat. Pendekatan taktis dan strategis tersebut salah satunya adalah mengajak semua peserta untuk berdiskusi atau sesi sharing feeling/ berbagi perasaan secara informal dengan peserta program League of Change. Rumah Cemara melakukan sharing secara rutin setelah melaksanakan program League of Change, peserta dikumpulkan untuk sesi sharing feeling/ berbagi perasaan informal yang berisi saling menceritakan permasalahan individu dan saling membantu untuk mengatasi masalah yang dihadapi. Dalam sharing feeling ini biasanya aktivis dari Rumah Cemara memberikan pengertian mengenai HIV/AIDS, penularan virus tersebut, cara menanggulanginya dan yang terpenting adalah mengubah stigma HIV/AIDS dimulai dari diri sendiri lalu ke masyarakat.

AIDS merupakan kumpulan gejala penyakit yang diakibatkan karena menurunnya kekebalan tubuh oleh virus HIV. Orang yang telah terinfeksi HIV akan mudah diserang beberapa jenis penyakit (sindrom) yang kemungkinan tidak mempengaruhi orang dengan sistem 
kekebalan tubuh yang sehat. Penyakit tersebut dikenal sebagai infeksi oportunistik. Seseorang yang terinfeksi HIV dapat tetap sehat selama bertahun-tahun tanpa ada tanda fisik atau gejala infeksi. Orang yang terinfeksi virus tetapi tanpa gejala disebut HIV Positif. Sedangkan jika gejala tersebut muncul, maka dinamakan infeksi HIV bergejala atau penyakit HIV lanjutan.

Mengingat bahwa HIV/AIDS dianggap sebagai penyakit yang belum ada obatnya, dan pemikiran masyarakat atas penyakit tersebut dianggap muncul karena tindakan-tindakan yang menyimpang, antara lain seperti seks bebas, pemakaian narkoba dan sebagainya, maka masyarakat menjatuhkan sanksi sosial kepada pengidap maupun keluarganya. Oleh sebab itu masyarakat akan menjauhkan diri dari pergaulan dengan pengidap penyakit HIV/AIDS, anggapan tersebut mempunyai kepercayaan bahwa HIV/AIDS adalah ganjaran tingkah laku buruk yang menyangkut aturan moral.

Hal tersebut antara lain disebabkan masih kuatnya pandangan masyarakat pada umumnya terhadap HIV/AIDS yang merupakan penyakit menular seksual dan mempunyai stigma dalam budaya negara Indonesia. Pembicaraan tentang penyakit ini biasanya menimbulkan reaksi emosional yang erat hubungannya dengan keadaan moralitas. Mereka yang tertular penyakit ini dianggap kotor, tidak bermoral dan berdosa. Penilaian negatif tersebutlah yang menyebabkan penderita malu untuk pergi berobat sehingga cenderung menyembunyikan penyakitnya, sehingga akan membahayakan untuk masyarakat luas.

Orang dengan HIV/AIDS atau biasa disebut ODHA tidak hanya menghadapi masalah fisik yang melemah, tetapi masalah psikososial yang berkaitan dengan penyakit kronis. Penelitian menunjukkan bahwa terdapat tiga tantangan penyesuaian yang harus dihadapi ODHA yaitu: menghadapi permasalahan yang berkaitan dengan reaksi lingkungan sosial terhadap penyakit dengan stigma negatif, menghadapi kemungkinan bahwa kematian dapat datang kapan saja dan mengembangkan strategi untuk mempertahankan kesehatan fisik dan emosional (K. Siegel \& Krauss dalam Taylor, 1997).

Ketakutan dan stigma negatif ini merupakan sebab eksternal yang menimbulkan permasalahan sosial pada ODHA. Selain penyebab eksternal, permasalahan fisik dan psikologis yang dialami ODHA juga menimbulkan perubahan relasi sosial ODHA. Membangkitkan kepercayaan diri dengan cara memberikan motivasi kepada diri sendiri adalah bukan hal yang mudah, apalagi membangkitkan kepercayan diri orang lain. Tidak mudah bagi ODHA untuk membangun kepercayaan dirinya dan masyarakat kepada dirinya.

Salah satu hal bisa dilakukan adalah berpartisipasi untuk mengikuti kegiatan yang mempunyai nilai positif baik bagi dirinya atau masyarakat seperti ajang olah raga. Dengan mengikuti ajang olahraga diharapkan ODHA bisa membangun kembali kepercayaan dirinya dan lingkungan terdekatnya seperti keluarga dan ada perubahan terhadap perilaku ODHA kepada hal yang lebih positif.

Berdasarkan penjelasan tersebut di atas, selanjutnya dapat diuraikan secara lebih rinci dalam bentuk hal-hal yang ingin diketahui dalam penelitian ini yaitu latar belakang dilaksanakannya program League of Change , pola komunikasi antara partisipan program League of Change dan dampak yang dirasakan oleh ODHA setelah mengikuti program League of Change.

\section{METODE PENELITIAN}

Penelitian ini berangkat dari suatu program yang berlatar belakang alamiah, dengan maksud menafsirkan fenomena yang terjadi dan dilakukan dengan melibatkan berbagai metode yang ada. Penelitian ini mengharuskan peneliti untuk melakukan wawancara mendalam dan observasi langsung ke lapangan untuk menelaah dan memahami, sikap, pandangan, perasaan dan perilaku individu atau sekelompok orang. Moleong (2007) mendefinisikan penelitian kualitatif sebagai penelitian yang bermaksud untuk memahami fenomena tentang apa yang dialami oleh subjek penelitian misalnya perilaku, persepsi, motivasi, tindakan secara holistik dan dengan cara deskripsi dalam bentuk kata-kata dan bahasa, pada suatu konteks khusus yang alamiah dan dengan memanfaatkan berbagai metode alamiah.

Bogdan dan Taylor (1975) mendefinisikan bahwa metodologi kualitatif sebagai prosedur penelitian yang menghasilkan data-data deskriptif berupa kata-kata tertulis atau lisan dari orang-orang dan perilaku yang dapat diamati. Menurut mereka, pendekatan ini 
diarahkan pada latar dan individu secara utuh. Jadi, dalam hal ini tidak boleh mengisolasikan individu atau organisasi ke dalam variabel atau hipotesis, tetapi perlu memandangnya sebagai bagian dari sesuatu keutuhan. (Moleong, 2007: 4).

Pendekatan kualitatif pada penelitian ini dipandang lebih relevan dan cocok karena bertujuan menggali dan memahami apa yang tersembunyi dibalik implementasi program League of Change dalam perubahan perilaku ODHA. Hal ini sejalan dengan pendapat Denzin dan Lincoln (dalam Creswell, 1998: 15), bahwa:

"Penelitian kualitatif memiliki fokus pada banyak metode, meliputi pendekatan interpretif dan naturalistik terhadap pokok persoalannya. Ini berarti bahwa para peneliti kualitatif mempelajari segala sesuatu di lingkungannya yang alami, mencoba untuk memahami atau menafsirkan fenomena menurut makna-makna yang diberikan kepada fenomena tersebut oleh orang-orang. Penelitian kualitatif meliputi penggunaan dan pengumpulan berbagai bahan empiris yang diteliti-penelitian kasus, pengalaman pribadi, introspektif, kisah kehidupan, wawancara, pengamatan, sejarah, interaksi dan naskah-naskah visual yang menggambarkan momen-momen problematik dan kehidupan sehari-hari serta makna yang ada di dalam kehidupan individu".

Dalam tradisi penelitian kualitatif dikenal terminologi studi kasus (case study) sebagai sebuahjenis penelitian. Menurut Creswell(1998: 37), fokus studi kasus adalah spesifikasi kasus dalam suatu kejadian, baik itu yang mencakup individu, kelompok budaya ataupun suatu potret kehidupan. Penelitian ini memusatkan diri secara intensif pada satu objek tertentu yang mempelajarinya sebagai suatu kasus. Selain itu, program League of Change merupakan sistem yang terikat oleh waktu dan tempat karena program tersebut rutin diadakan setahun sekali. Dalam penelitian ini, peneliti menggunakan berbagai sumber informasi dalam pengumpulan datanya untuk memberikan gambaran secara terinci dan mendalam tentang program League of Change. Data studi kasus dapat diperoleh dari semua pihak yang bersangkutan, dengan kata lain data dalam studi ini dikumpulkan dari berbagai sumber (Nawawi, 2003). Peneliti juga harus menghabiskan waktu untuk menggambarkan perubahan perilaku ODHA menghadapi stigma HIV/AIDS di Rumah Cemara.
Dengan kata lain, studi kasus merupakan penelitian manakala peneliti menggali suatu fenomena tertentu (kasus) dalam suatu waktu dan kegiatan (program, event, proses, institusi atau kelompok sosial) serta mengumpulkan informasi secara terinci dan mendalam dengan menggunakan berbagai prosedur pengumpulan data selama periode tertentu. Creswell mengungkapkan bahwa apabila kita akan memilih studi untuk suatu kasus, dapat dipilih dari beberapa program studi atau sebuah program studi dengan menggunakan berbagai sumber informasi yang meliputi observasi, wawancara, materi audio-visual, dokumentasi dan laporan. Konteks kasus dapat "mensituasikan" kasus di dalam setting fisik, sosial, sejarah ataupun ekonomi. Sedangkan fokus di dalam suatu kasus dapat dilihat dari keunikannya, memerlukan suatu studi (studi kasus intrinsik) atau dapat pula menjadi suatu isu dengan menggunakan kasus sebagai instrumen untuk menggambarkan isu tersebut (studi kasus instrumental) (Creswell, 1998: 61-62).

Tujuan studi kasus menurut Nazir (1985: 66) adalah memberikan secara mendetail tentang latar belakang, sifat-sifat serta karakterkarakter khas dari kasus. Masalah penelitian ini adalah suatu proses, oleh karenanya hal-hal yang perlu dikaji bersifat nyata. Data mengenai proses ini diperoleh melalui pengamatan yang teliti dan spesifik. Dalam rangka menguji hasil pengamatan perlu ada pengulangan kembali pengamatan yang lebih spesifik untuk kemudian kedua hasilnya diperbandingkan melalui metode wawancara.

Seturut dengan apa yang dikemukakan Creswell, maka pada penelitian tentang kasus Program League of Change dalam perubahan perilaku ODHA menghadapi stigma HIV/AIDS di Rumah Cemara dengan mempergunakan beberapa sumber informasi seperti melalui wawancara dengan informan, studi kepustakaan dan observasi.

Penelitian yang dilakukan di Rumah Cemara mengenai implementasi program League of Change dalam perubahan perilaku ODHA terhadap HIV/AIDS menggunakan metode penelitian dengan jenis studi kasus instrumental tunggal. Creswell menjelaskan bahwa studi kasus intrumental tunggal adalah penelitian studi kasus yang dilakukan dengan menggunakan sebuah kasus untuk menggambarkan suatu isu atau perhatian. Dengan kata lain, kasus 
diposisikan sebagai sarana (instrumen) untuk menunjukan penjelasan yang mendalam dan pemahaman tentang sesuatu yang lain dari yang biasa dijelaskan. Melalui kasus yang ditelitinya, peneliti bermaksud menunjukan adanya sesuatu yang khas yang dapat dipelajari dari suatu kasus tersebut, yang berbeda dari penjelasan yang diperoleh dari objek-objek lain.

Pada kasus ini, program League of Change digunakan sebagai alat yang menghorisontalkan kelanjutan Kampanye Indonesia Tanpa Stigma setiap tahunnya oleh Rumah Cemara. Tidak hanya itu, keunikan dari kasus program program League of Change berbeda dengan program Rumah Cemara yang lainnya. Pasalnya dari beberapa program yang dilaksanakan oleh Rumah Cemara, program ini yang dianggap paling efektif untuk memberikan informasi mengenai HIV/AIDS dan mendapatkan penghargaan dari beberapa lembaga nasional dan internasional, salah satunya dari Kementrian Pemuda dan Olahraga Republik Indonesia.

Penelitian ini juga mengunakan prinsip dasar konstruktivisme, karena tindakan objek penelitian ditentukan oleh konstruk diri sekaligus juga konstruk lingkungan luar dari diri. Selain itu konstruktivisme meyakini bahwa pengetahuan bukanlah hasil sekali jadi, melainkan proses panjang sejumlah pengalaman. Menurut Ardianto dan Q Annes (2011: 154) konstruktivisme merupakan salah satu filsafat pengetahuan yang menekankan bahwa pengetahuan individu adalah hasil konstruksi (bentukan) individu sendiri.

Konstruktivisme dalam kehidupan selama ini merupakan himpunan dan pembinaan dari pengalaman individu. Konstruktivisme menyatakanbahwaindividumenginterpretasikan dan beraksi menurut kategori konseptual dari pikiran. Realitas tidak menggambarkan diri individu, namun hasil yang disaring melalui cara pandang orang terhadap realitas tersebut.

\section{HASIL DAN PEMBAHASAN}

Berdasarkan dari hasil wawancara informan yang terlibat dalam implementasi program League Of Change, peneliti melihat bahwa program ini dilatarbelakangi demi kepentingan tiga pihak yaitu ODHA, organisasi dan masyarakat. Latar belakang implementasi program League of Change melihat bahwa ODHA adalah salah satu dasar pemikiran
Rumah Cemara untuk membuat program berupa turnamen sepak bola. Ada enam poin latar belakang dengan kepentingan ODHA pada implementasi program League Of Change, yaitu sebagai berikut: (1) memberikan apresiasi kepada ODHA untuk melakukan kegiatan yang positif seperti olah raga; (2) meningkatkan kualitas hidup dan mengubah pola hidup menjadi lebih positif; (3) membuat perubahan atau titik balik bagi ODHA; (4) mengadakan sesi sharing untuk diskusi mengenai pencegahan penularan HIV/AIDS; dan (5) mengejar prestasi di bidang sepak bola.

Latar belakang dengan kepentingan ODHA, dapat dilihat dengan teori interaksi simbolik yang dimana George Herbert Mead mencetuskan teori interaksi simbolik dengan tiga konsep mendasar yaitu: Mind, Self and Society. Tiga konsep ini saling mempengaruhi satu sama lain dalam term interaksionisme simbolik. Pikiran manusia (mind) dan interaksi sosial (diri/self dengan yang lain) digunakan untuk menginterpretasikan dan memediasi masyarakat (society) di mana kita hidup. Makna berasal dari interaksi dan tidak dari cara yang lain. Pada saat yang sama "pikiran" dan "diri" timbul dalam konteks sosial masyarakat. (Ardianto \& Q. Annes, 2011: 136)

Implementasi program League of Change yang dilakukan oleh Rumah Cemara menurut teori interaksi simbolik yang diungkapkan oleh Mead dimulai dengan pikiran (mind) bahwa program League of Change yang mempunyai tujuan untuk menghapuskan stigma ODHA merupakan sebuah simbol, kemudian diproses di dalam mind pihak Rumah Cemara yang mendorong Rumah Cemara sebagai sebuah LSM atau self melakukan sebuah kegiatan interaksi dalam sebuah program League of Change untuk ODHA dan masyarakat (society).

Mead mendefinisikan pikiran (mind) sebagai kemampuan untuk mengunakan simbol yang mempunyai makna sosial yang sama, dan Mead percaya bahwa manusia harus mengembangkan pikiran melalui interaksi dengan orang lain. Simbol diberikan secara verbal dan nonverbal yang diatur dalam polapola untuk mengekspresikan pemikiran dan perasaan yang dimiliki bersama, yang Mead sebut sebagai simbol signifikan. Simbol signifikan dalam penelitian ini adalah stigma ODHA, stigma bahwa ODHA tidak dapat melakukan kegiatan olah raga karena dianggap 
mempunyai kondisi fisik yang lemah dan tidak berdaya. Dengan simbol tersebut, Rumah Cemara melakukan kegiatan berinteraksi dalam sebuah program bernama League of Change.

Dengan menggunakan simbol yang berada dalam bahasa dan kegiatan interaksi dengan orang lain, Rumah Cemara mengembangkan apa yang dikatakan Mead sebagai pikiran. Dan hal tersebut dapat membuat Rumah Cemara mampu menciptakan setting interior bagi masyarakat yang beroperasi di luar diri ODHA. jadi, pikiran dapat menginternalisasi masyarakat. Akan tetapi, pikiran tidak hanya bergantung pada masyarakat, Mead menyatakan bahwa keduanya mempunyai hubungan timbal balik. Pikiran merefleksikan dan menciptakan dunia sosial. Ketika seseorang belajar, ia belajar berbagai norma sosial dan budaya yang mengikatnya. Di samping itu ia juga mempelajari cara-cara untuk membentuk dan mengubah dunia sosial melalui interaksi.

Selain itu, Rumah Cemara juga mengadakan sesi sharing feeling yang berisi diskusi mengenai pencegahan penularan HIV/AIDS untuk membuat perubahan atau titik balik bagi ODHA. melalui komunikasi kelompok ini, ODHA dapat mengatur makna dari situasi barunya. Mead berpegang bahwa tanpa ransangan dan interaksi dengan orang lain, orang tidak akan mampu mengadakan pembicaraan dalam dirinya sendiri atau mempertahankan pemikirannya.

Latar belakang lainnya adalah untuk kepentingan organisasi, organisasi yang peneliti maksud disini adalah Rumah Cemara sebagai penggagas dan pelaksana program League of Change. Rumah Cemara mempunyai empat hal yang dilihat dari kepentingan organisasi, yaitu sebagai berikut: (1) mewujudkan film dokumenter yang berjudul 'Kicking It'; (2) motivasi dari Homeless World Cup; (3) membuka jaringan antar komunitas di seluruh Indonesia; dan (4) sebagai hiburan antar komunitas selain ODHA.

Rumah Cemara ingin mewujudkan film dokumenter yang berjudul 'Kicking $I t$ ' yang mendapatkan motivasi dari Homeless World Cup. Menurut Mead, salah satu aktivitas penting yang diselesaikan individu melalui pemikiran adalah pengambilan peran (role taking), atau kemampuan untuk secara simbolik menempatkan dirinya sendiri dalam diri khayalan orang lain. Rumah Cemara mengambil peran yang dilihatnya dari film 'Kicking It' untuk mewujudkan turnamen sepak bola seperti Homeless World Cup.

Dengan membuka jaringan antar komunitas di seluruh Indonesia, Rumah Cemara ingin melakukan sebuah tindakan simbolis yang dapat membantu menjelaskan bagaimana perasaan mengenai diri ODHA di antara komunitaskomunitas. Tindakan simbolis itu dengan mengundang peserta-peserta yang berasal dari luar Kota Bandung. Dan latar belakang sebagai hiburan antar komunitas selain ODHA akan memungkinkan untuk mengembangkan kapasitas orang lain untuk berempati dengan ODHA.

Latar belakang diadakannya program League of Change tidak terlepas dari kepedulian Rumah Cemara kepada masyarakat menghadapi isu HIV/AIDS. Maka dari itu dari hasil penelitian yang didapatkan di lapangan, peneliti melihat adanya kepentingan masyarakat dalam program League Of Change ini. Ada enam poin latar belakang yang meliputi kepentingan masyarakat, yaitu sebagai berikut: (1) Kampanye Indonesia Tanpa Stigma yang masuk ke semua kalangan masyarakat; (2) memberi pembuktian kepada masyarakat bahwa ODHA dapat membuat prestasi; (3) menghapus stigma jika ODHA dianggap tidak mampu berolahraga karena mempunyai fisik yang lemah; (4) menghapus stigma yang beredar bahwa ODHA harus dijauhi; dan (5) membuat masyarakat untuk lebih memahami permasalahan HIV/AIDS dengan dilibatkan dalam League Of Change.

Mead berargumen dalam West \& Turner (2009: 107) bahwa interaksi mengambil tempat di dalam sebuah struktur sosial yang dinamis seperti budaya, masyarakat dan sebagainya. Mead mendefinisikan masyarakat (society) sebagai jejaring hubungan sosial yang diciptakan manusia. Individu-individu terlibat di dalam masyarakat melalui perilaku yang mereka pilih secara aktif dan sukarela. Masyarakat yang terlibat dalam program League of Change merupakan individu yang aktif dan sukarela tanpa paksaan untuk mendukung.

Masyarakat terdiri atas individu-individu dan Mead berbicara mengenai dua bagian penting masyarakat yang mempengaruhi pikiran dan diri. Pemikiran Mead mengenai orang lain secara khusus (particular others) merujuk pada individu-individu dalam masyarakat yang signifikan bagi kita, seperti 
anggota keluarga, teman dan kolega. Peserta program League of Change melihat orang lain secara khusus tersebut untuk mendapatkan rasa penerimaan sosial dan rasa mengenai diri individunya. Ketika ODHA berpikir mengenai pendapat orang lain, dia sedang mendapatkan rasa mengenai diri dari orang lain secara khusus tersebut.

Generalized other atau orang lain secara umum, Mead berpendapat bahwa cara pandang dari sebuah kelompok sosial atau budaya secara keseluruhan. Hal ini diberikan oleh masyarakat kepada kita dan "sikap dari orang lain secara umum adalah sikap dari keseluruhan komunitas" (West \& Turner, 2012: 108). Orang lain secara umum memberikan informasi mengenai peranan, aturan dan sikap yang dimiliki bersama oleh komunitas.

Dalam sebuah interaksi, aktor harus memperhatikan orang lain dan menentukan kapan dan bagaimana cara menyesuaikan aktivitas mereka terhadap orang lain. Pendapat Blumer dapat diinterpretasikan bhawa, kemampuan berpikir yang baik dari seseorang, termasuk kreatifitasnya akan mempermudah mereka dalam menyesuaikan diri dengan siapa dirinya berinteraksi, bagaimana cara berinteraksi yang harus dijalankan, dan bahkan mungkin berbagai hal yang dapat ditemukan ataua didapatkan dari interaksi dengan orang yang bersangkutan.

Dalam program League of Change aktor yang berperan adalah panitia yang harus memperhatikan masyarakat dalam menentukan kapan dan bagaimana tahap-tahap pemberian informasi dan melibatkan kontribusi masyarakat tanpa adanya paksaan. Dengan kreatifitas yang dimiliki Rumah Cemara, panitia menggunakan kedekatannya dengan masyarakat sekitar untuk meminta bantuan. Bantuan tersebut macammacam bentuknya, peminjaman $\mathrm{WC}$, mengatur lahan parkir, atau berjualan makanan dan minuman. Hal tersebut dilakukan bukan hanya semata ingin melibatkan masyarakat, tetapi untuk menyisipkan pesan-pesan yang ingin Rumah Cemara sampaikan kepada masyarakat. Pesan yang berisi pesan-pesan mengenai HIV/ AIDS, penularan dan pencegahannya diberikan oleh panitia.

Mead dan Blumer (dalam West \& Turner, 2012: 103) memberikan asumsi bahwa orang dan kelompok dipengaruhi oleh proses sosial dan budaya, artinya ada norma-norma sosial yang membatasi perilaku individu. Budaya sangat kuat dalam mempengaruhi perilaku dan sikap yang dianggap penting dalam konsep diri. Seperti peneliti ketahui bahwa ODHA mempunyai stigma yang akhirnya membatasi perilaku dan sikap individu tersebut.

Stigma ODHA berasal dari cara penularan yang dianggap melanggar norma-norma sosial dan norma agama. Penularannya sendiri berasal dari tiga sumber, yaitu: (1) darah, melalui jarum suntik yang dipakai secara bergantian (narkotika) atau jarum tattoo; (2) cairan kelamin yang ditularkan melalui hubungan seksual dengan berganti-ganti pasangan; dan (3) ASI ibu HIV/AIDS yang menyusui bayinya. Dua dari tiga cara penularan itu menyalahi norma sosial dan norma agama yang berada di Indonesia, maka dari itu ODHA membatasi perilaku dan sikap yang dianggap penting dalam konsep diri.

Pola komunikasi yang terjadi di program League Of Change dibagi menjadi dua proses komunikasi, yaitu proses komunikasi antara komunitas dengan ODHA dan komunitas dengan masyarakat. Proses komunikasi antara komunitas dengan ODHA dilakukan dalam komunikasi kelompok yang terjadi pada saat sesi sharing feeling dimana situasi sudah santai, yaitu setelah peserta beristirahat dari turnamen sepak bola. Dan lokasi yang intim dan santai sesuai dengan keadaan saat itu, untuk tim pria lokasi sesi sharing feeling biasanya di rumah singgah atau mess yang disediakan panitia, sedangkan untuk tim wanita lokasinya di Lapangan Bawet.

Pesan yang diberikan saat sesi sharing feeling adalah latar belakang, stigma dan diskriminasi apa yang diterimanya, apa yang sedang dirasakan, sudah mendapatkan manfaat apa saja hari itu serta pengalaman peserta. Pesan yang diberikan dalam diskusi-pun melalui komunikasi dua arah, antara panitia dan peserta. Dan juga menggunakan bahasa yang informal agar tidak ada gap antara panitia sebagai komunikator dan peserta sebagai komunikan.

Sedangkan proses komunikasi antara komunitas dengan masyarakat dalam memberikan informasi melalui berbagai macam saluran komunikasi seperti media massa, media sosial, media visual dan media yang dikembangkan oleh Rumah Cemara. Informasi itu adalah penghapusan stigma, peningkatan kualitas hidup ODHA, serta edukasi mengenai HIV/AIDS dan drugs. Peneliti memperoleh 
data penelitian bahwa komunikasi kelompok menjadi bagian yang mendominasi proses komunikasi di program League of Change.

Kelompok dalam penelitian ini merupakan sekumpulan ODHA yang mempunyai tujuan bersama dan berinteraksi satu sama lain untuk mencapai tujuan bersama yaitu memberikan pembuktian yang positif kepada diri sendiri dan orang lain mengenai stigma HIV/AIDS, mengenal satu sama lainnya dan memandang mereka sebagai bagian dari kelompok tersebut. Komunikasi kelompok ini dilakukan dalam kegiatan penyampaian pesan yang bersifat informal dari panitia kepada peserta pada saat sesi sharing feeling yang dilakukan setelah turnamen sepak bola selesai.

Komunikasi kelompok dalam program League of Change digunakan untuk saling bertukar informasi mengenai HIV/AIDS, menambah pengetahuan, memperteguh atau mengubah sikap perilaku, mengembangkan kesehatan jiwa dan meningkatkan kesadaran. Menurut Effendy (2000:71) Dalam situasi kelompok terdapat hubungan psikologis, orangorang yang terikat oleh hubungan psikologis itu tidak selalu berada secara bersama-sama di suatu tempat. Mereka bisa saja berpisah tetapi hubungan psikologis menyebabkan mereka berkumpul bersama-sama secara berulangulang. Kelompok ini juga diperlukan kesadaran pada anggota-anggotanya akan ikatan yang sama yang mempersatukan mereka.

Berdasarkan peenyataan Effendi tersebut, peneliti melihat realita yang terjadi di program League of Change bahwa panitia dan peserta terikat oleh hubungan psikologis karena mempunyai latar belakang kesehatan yang sama, yaitu mengidap HIV/AIDS. Dan partisipan program League of Change tidak harus selalu berada secara bersama-sama di suatu tempat, karena mengingat peserta yang berasal dari berbagai provinsi di Indonesia. Mereka bisa saja berpisah tetapi hubungan psikologis menyebabkan mereka berkumpul bersama-sama secara berulang-ulang. Hal tersebut terlihat ketika peserta sudah kemabli ke daerah tempat tinggalnya masing-masing, tetapi komunikasi secara personal masih terus berjalan.

Dilihat dari asumsi Teori Interaksi Simbolik yang pertama yaitu pentingnya makna bagi perilaku manusia, Mead berpegang bahwa individu membentuk makna melalui proses komunikasi karena makna tidak bersifat intrinsik terhadap apapun. Dibutuhkan konstruksi interpretif di antara orang-orang untuk menciptakan makna. Bahkan tujuan dari interaksi adalah untuk menciptakan makna, karena makna diciptakan dalam interaksi antar manusia. Interaksi untuk menkontruksi interpretif dalam program League of Change dilakukan dengan proses komunikasi.

Sesuai dengan pemikiran-pemikiran Mead, salah satu ide dasar dari teori interaksi simbolik adalah Mind (pikiran) yang dimana Mead artikan sebagai kemampuan untuk menggunakan simbol yang mempunyai makna sosial yang sama, dimana tiap individu harus mengembangkan pikiran mereka melalui interaksi dengan individu lain. Agar mempunyai makna sosial yang sama, individu harus melakukan interaksi dengan individu lainnya, yaitu melalui proses komunikasi. Untuk melihat proses komunikasi yang berlangsung pada program League of Change, peneliti menggunakan teknik wawancara mendalam juga participant observation. Dari hasil wawancara dan pengamatan yang dilakukan, ditemukan bahwa proses komunikasi yang terjadi pada program League of Change dapat dibedakan menjadi dua tahap, yaitu: proses komunikasi antara komunitas dengan peserta dan proses komunikasi antara komunitas dengan masyarakat.

Dampak yang dirasakan setelah mengikuti program League of Change dibagi menjadi dua kategori yaitu dampak internal dan dampak eksternal. Untuk dampak internal yang dirasakan oleh ODHA adalah dapat mengatur pola hidup yang lebih sehat, meningkatkan kepercayaan dirinya dan mendapatkan pembuktian bahwa ODHA bisa mendapatkan prestasi. Sedangkan untuk dampak eksternal yang dirasakan oleh ODHA adalah mengurangi stigma ODHA dari lingkungan keluarga dan masyarakat, dapat bersosialisasi sambil memberikan informasiinformasi mengenai HIV/AIDS kepada temantemannya dan mendapatkan kepercayaan untuk ikut ambil peran di masyarakat.

Konsep diri memberikan motif penting untuk perilaku, pemikiran bahwa keyakinan, nilai, perasaan, penilaian-penilaian mengenai diri mempengaruhi perilaku adalah sebuah prinsip penting pada teori interaksi simbolik (West \& Turner, 2012: 102). Mead berpendapat bahwa karena manusia memiliki diri, mereka 
memiliki mekanisme untuk berinteraksi dengan dirinya sendiri. Mekanisme ini digunakan untuk menuntun perilaku dan sikap. Mead juga melihat diri sebagai sebuah proses bukan struktur. Yang dapat berkembang setiap individu melakukan interaksi dengan individu lainnya.

Teori interaksi simbolik dipengaruhi oleh struktur sosial yang membentuk atau menyebabkan perilaku tertentu yang kemudian membentuk simbolisasi dalam interaksi sosial masyarakat. Teori interaksi simbolik menuntut setiap individu untuk harus proaktif, refleksif dan kreatif, dapat menafsirkan, menampilkan perilaku yang unik, rumit dan sulit diinterpretasikan. Teori interaksi simbolik menekankan dua hal. Pertama, manusia dalam masyarakat tidak pernah lepas dari interaksi sosial. Kedua, interaksi dalam masyarakat terwujud dalam simbol-simbol tertentu yang sifatnya cenderung dinamis.

Mead mendefinisikan masyarakat (society) sebagai jejaring hubungan sosial yang diciptakan manusia. Individu-individu terlibat di dalam masyarakat melalui perilaku yang mereka pilih secara aktif dan sukarela. Masyarakat yang terlibat dalam program League of Change merupakan individu yang aktif dan sukarela tanpa paksaan untuk mendukung.

\section{SIMPULAN}

Implementasi program League Of Change dilatarbelakangi demi kepentingan tiga pihak, yaitu ODHA, organisasi dan masyarakat. Latar belakang dengan kepentingan ODHA seperti memberikan apresiasi kepada ODHA untuk melakukan kegiatan yang positif seperti olah raga, meningkatkan kualitas hidup dan mengubah pola hidup menjadi lebih positif, membuat perubahan atau titik balik bagi ODHA, dan mengejar prestasi di bidang sepak bola. Untuk kepentingan organisasi Rumah Cemara adalah untuk mewujudkan film dokumenter yang berjudul 'Kicking It'; ingin membuat turnamen seperti Homeless World Cup, bisa membuka jaringan antar komunitas di seluruh Indonesia dan menjadi ajang hiburan antar komunitas selain ODHA. Sedangkan dari faktor kepentingan masyarakat untuk memberi pembuktian kepada masyarakat bahwa ODHA dapat membuat prestasi, dapat menghapus stigma jika ODHA dianggap tidak mampu berolahraga karena mempunyai fisik yang lemah, bisa menghapus stigma yang beredar bahwa ODHA harus dijauhi.

Pola komunikasi yang terjadi di program League Of Change dibagi menjadi dua proses komunikasi, yaitu proses komunikasi antara komunitas dengan ODHA dan komunitas dengan masyarakat. Proses komunikasi antara komunitas dengan ODHA dilakukan dalam komunikasi kelompok yang terjadi pada saat sesi sharing feeling melalui komunikasi tatap muka. Sedangkan proses komunikasi antara komunitas dengan masyarakat melalui berbagai macam saluran komunikasi seperti komunikasi tatap muka, media massa, media sosial, media visual dan media yang dikembangkan oleh Rumah Cemara.

Dampak yang dirasakan ODHA setelah mengikuti program League of Change dibagi menjadi dua kategori yaitu dampak internal dan dampak eksternal. Untuk dampak internal yang dirasakan oleh ODHA adalah dapat mengatur pola hidup yang lebih sehat, meningkatkan kepercayaan dirinya dan mendapatkan pembuktian bahwa ODHA bisa mendapatkan prestasi. Sedangkan untuk dampak eksternal yang dirasakan oleh ODHA adalah mengurangi stigma ODHA dari lingkungan keluarga dan masyarakat, dapat bersosialisasi sambil memberikan informasi-informasi mengenai HIV/AIDS kepada teman-temannya dan mendapatkan kepercayaan untuk ikut ambil peran di masyarakat.

Saran-saran yang disampaikan berkaitan dengan hasil penelitian yang diperoleh, antara lain: (1) Implementasi program League of Change dilatarbelakangi demi kepentingan tiga pihak, yaitu ODHA, organisasi dan masyarakat. Tetapi tidak ada bagi kepentingan pemerintah, hal ini dikarenakan belum adanya rasa percaya Rumah Cemara kepada pemerintah. Rumah Cemara sebaiknya lebih membuka diri dan berpikiran positif kepada pemerintah karena akan lebih baik jika pemerintah dan Rumah Cemara dapat bekerjasama untuk mencapai tujuan dari program League Of Change, (2) Rumah Cemara diharapkan lebih proaktif dalam mensosialisasikan eksistensi dan aktivitasnya kepada masyarakat, agar semakin banyak lagi ODHA dan masyarakat untuk terlibat dalam program League Of Change. Untuk itu diharapkan pula kerjasama dari pihak-pihak seperti pemerintah dan media massa dalam melakukan sosialisasi. Selain itu, diharapkan 
pula komunitas-komunitas lain untuk dilibatkan dalam program League Of Change agar program tersebut menjadi lebih bervariasi, dan (3) Peran dan dukungan dari keluarga dan masyarakat sangat diharapkan untuk menghilangkan stigma yang selama ini melekat pada diri ODHA. Sehingga ODHA akan lebih mudah berperan aktif dalam rangka pencegahan penularah HIV/AIDS dan dapat meningkatkan kualitas hidupnya.

\section{DAFTAR PUSTAKA}

Ardianto, E. \& Q-Annes, B. (2011). Filsafat ilmu komunikasi. Bandung: Simbiosa Rekatama Media.

Bogdan, R \& Taylor, S. (1975). Introducing to qualitative methods: phenomenological.
New York: A Wiley Interscience Publication.

Creswell, J. W. (1998). Qualitative inquiry and research design: choosing among five tradition. Sage Publications, Inc.

Effendy, O. U. (2000). Ilmu teori dan filsafat komunikasi. Bandung: Remaja Rosdakarya.

Moleong, L. (2007). Metodologi penelitian kualitatif. Edisi Revisi. Bandung: Remaja Rosdakarya.

Nazir, M. (1985). Metode penelitian. Bandung: Grafika Indonesia.

Taylor, S. E., Peplau, L. A. \& Sears, D. O. (1997). Social psychology. New Jersey: Prentice Hall.

West, R. \& L.H. Turner. (2009). Introducing communication theory: analysis and application. New York: McGraw-Hill. 